\title{
Extent of Utilization of Android App on Coconut Expert System and its Effectiveness as Perceived by the Coconut Farmers in Kanyakumari District of Tamil Nadu, India
}

\author{
A. Aravind", R. Raja Sekaran, C. Karthikeyan and R. Gangai Selvi \\ Department of Social Sciences, Agricultural College and Research Institute, Killikulam, \\ Thoothukudi, Tamil Nadu, India \\ *Corresponding author
}

\section{A B S T R A C T}

Keywords

Perception, Android app, Extent of utilization and their effectiveness

Article Info

Accepted:

26 October 2019

Available Online:

10 November 2019
India predominantly an agrarian economy since 70 per cent of the rural households still depend on agriculture as livelihood and the country has been successful in attaining self-sufficiency in food production due to the successful dissemination of improved technologies in agriculture facilitated by public and private institutions and adopted by millions of farmers. The study was undertaken to find out the extent of utilization of android app on coconut expert system and its effectiveness as perceived by the coconut farmers. The study was conducted in the Kanyakumari district of Tamil Nadu since this district has largest area under coconut cultivation when compared to other districts. The degree of effectiveness of coconut expert system can be assessed through respondent perception. The results of the study will helps the designer of the expert system to modify the content and procedures to suit the expectation of end users. The extension workers have to conduct demonstrations, awareness creation and training to the users in handling and using various android app will help in improving their skills and effective utilization.

\section{Introduction}

India predominantly an agrarian economy since 70 per cent of the rural households still depend on agriculture as a livelihood and the country has been successful in attaining selfsufficiency in food production due to the successful dissemination of improved technologies in agriculture facilitated by public and private institutions and adopted by millions of farmers. Mobile device (Smart phone) has become the need of every common man and is reached in the hands of rich and poor. There are enormous applications 
developed to serve the large number of operation. The Government is taking effort to develop many mobile applications for farmers in India to help farmers in different ways and provide assistance through mobile application in different field of agriculture. Rizvi (2010) observed that access to mobile based advisory services can help to reach poor farmers in remote/rural areas. Majority of the farmers had utilized the market information through SMS service (Sife et al., 2010).

Hiremath and Tiwari (2011) found that majority of them considered always comfortable to use Telephone followed by mobile. Expert system provides consistent answers for repetitive decisions, processes and tasks and holds significant level of information. The purpose of expert system is not to replace human experts, but to make their knowledge and experience more widely available and permits non- experts to work better (Tripathi, 2011). Keeping this in view the present research study was undertaken to find out the extent of utilization of android app on coconut expert system and its effectiveness as perceived by the coconut farmers.

\section{Materials and Methods}

The study was conducted in the kanyakumari district of Tamil Nadu since this district has largest area under coconut cultivation when compared to other districts. The kanyakumari district has nine blocks. Of the nine blocks, four blocks having maximum crop area under coconut crop has been selected for this study. From the selected four blocks, top two villages from each blocks having maximum area under coconut crop has been selected for the study. Thus, 120 farmers were selected as respondents for the study. Thus required number of respondents was selected by using proportionate random sampling technique and the distribution of respondents are presented in the Table 1.

\section{Result and Discussion}

\section{Farmer perception about the utilization of Coconut Expert System}

The degree of effectiveness of coconut expert system can be assessed through respondent perception. In this context perception is the process, by which one can be able to see, hear and understanding the technical content of the app. Hence it is assumed that greater the perception of coconut expert system by its users in terms of satisfaction derived from various components of coconut expert system, greater would be the viewer exposure. Farmer perception on different components of coconut expert system as perceived by the respondents is furnished in the Table 2.

Regarding perception, majority of the coconut farmers $(65.83 \%)$ were satisfied the technical information provided through coconut expert system but still 17.5 per cent of the respondents were not satisfied with the technical information provided in expert system. They felt that information regarding input sources and videos for explaining pest and disease management are inadequate. Major proportion of coconut farmers $(67.50 \%)$ was motivated to learn the subject matter through expert system. It might be because of detailed information provided related to every contents. Above half of the coconut farmers $(55.84 \%)$ felt satisfied on handling the expert system app. As the profile characters shows that most of the coconut farmers are mobile users that is they were exposed to some of the modern gadgets. More than half of the coconut farmers 55.84 per cent reacted that handling of coconut expert system was interesting to use. As mentioned earlier, coconut expert system was simple to operate and provided with detailed information are the reason for the satisfaction. Majority of the coconut farmers 44.17 per cent were satisfied towards possibility to repeated utilization the 
information. One-fourth 25.83 per cent of the coconut farmers were not satisfied towards possibility of updating the information. This is due to their adequate knowledge about the smartphone and its operations. Majority 47.50 per cent of the coconut farmers were satisfied on the completeness of provided coconut innovations. More than one-fourth 28.55 per cent of the coconut farmers were highly satisfied with the information provided. This may be due to the presence of detailed information on pest and disease management and functions of different machineries used for coconut cultivation are available. Major proportion 48.33 per cent of the coconut farmers was motivated to adopt the messages in their farm. They revealed that benefits of the complex practices which are provided. The results revealed that the provided information in the expert system are adequate and complete to motivate the farmers to enthusiastically involved in the coconut cultivation. Hence effort should be made to make it more motivating through of videos and pictures with hassle free navigation in order to get more users

\section{Perceived effectiveness of the coconut expert system}

Perception of various contents of the app on coconut expert system as evaluated by the respondents and also observed that seven sub components under message were presented in the Table 3.

Regarding effectiveness, more than half of the coconut farmers $(55.83 \%)$ of the respondents were satisfied on understanding of message. This is because messages were given in regional language and simple sentences were used. More than one-fourth 27.50 per cent of the coconut farmers were not satisfied. The varieties names were given in numerical (Eg. ALR (CN) 1), VHC 2 rather than vernacular names and chemical names for the insecticides made the farmer hard to grasp the message. Majority of the coconut farmers (59.17\%) were satisfied with the accuracy of provided messages are relevant to the coconut cultivation practices and inappropriate messages were totally avoided. Nearly half $(46.67 \%)$ of the coconut farmers were satisfied on explanation of complex ideas. Still one fourth $(29.16 \%)$ per cent of the coconut farmers were not satisfied. Because videos related to information are not provided in the expert system app. Two-fifth $(41.67 \%)$ of the coconut farmers were highly satisfied on the clarity of messages provided in the coconut expert system. The provided messages are in regional language and simple words are used.

Nearly half 45.83 per cent of the respondents were satisfied on appropriateness of message given in coconut expert system. Messages were given with appropriate title and cultivation practices are depicted to local condition. Majority 54.17 per cent of the coconut farmers were felt satisfied on the sub component reinforcement of key ideas and more than one-fourth 26.16 per cent of the coconut farmers were felt highly satisfied. More than two-fifth 44.17 per cent of the coconut farmers were satisfied on the multidisciplinary nature of the subject. Information on pest management are strengthened by giving clear information. It is found to be that content of the app need some more refinement in some of the aspects of Presentation of complex ideas, and relevancy of messages and incorporating multidisciplinary expert judgment on subjects.

Extent of utilization of android app on coconut expert system by the farmers for obtaining information on different areas related to coconut cultivation. In these study farmers perception regarding the utilization of android app on coconut expert system was asked. 
Table.1 Distribution of respondents drawn from various selected villages

\begin{tabular}{|c|c|c|c|}
\hline S. No. & Name of the villages & $\begin{array}{c}\text { Total number of } \\
\text { coconut growers }\end{array}$ & $\begin{array}{c}\text { Respondents } \\
\text { selected }\end{array}$ \\
\hline I. & Agastheeswaram block & & \\
\hline & South Thamaraikulam & 1337 & 12 \\
\hline & Ramapuram & 1805 & 16 \\
\hline II. & Rajakamangalam block & & \\
\hline & Rajakamangalam & 2682 & 24 \\
\hline & Neendakarai & 2860 & 25 \\
\hline III. & Kurunthencode block & 1325 & 12 \\
\hline & Chemponvilai & 1150 & 10 \\
\hline IV. & Lakshmipuram & & 11 \\
\hline & Thuckalay block & 1248 & 10 \\
\hline & Kalkulam & 1137 & $\mathbf{1 2 0}$ \\
\hline & Chadayamangalam & Total & $\mathbf{1 3 5 4 4}$ \\
\hline
\end{tabular}

(Source: Office of the Joint Director of Agriculture, Kanyakumari district- 2018)

Table.2 Distribution of respondents according to their perception about the utilization of coconut expert system

\begin{tabular}{|c|c|c|c|c|c|c|c|}
\hline S. No. & Perception statement & Highly s & tisfied & Satis & & Not $\mathrm{s}$ & fied \\
\hline & & Frequency & Per cent & Frequency & Per cent & Frequency & Per cent \\
\hline 1. & $\begin{array}{l}\text { Adequacy of technical } \\
\text { information provided }\end{array}$ & 20 & 16.67 & 79 & 65.83 & 21 & 17.5 \\
\hline 2. & $\begin{array}{l}\text { Elements on motivation } \\
\text { to learn the contents }\end{array}$ & 18 & 15.00 & 81 & 67.5 & 21 & 17.5 \\
\hline 3. & User friendly to handle & 40 & 33.33 & 67 & 55.84 & 13 & 10.83 \\
\hline 4. & $\begin{array}{l}\text { Interesting to utilize the } \\
\text { app }\end{array}$ & 36 & 30.00 & 67 & 55.84 & 17 & 14.16 \\
\hline 5. & $\begin{array}{l}\text { Possibility to update and } \\
\text { reutilize the information }\end{array}$ & 36 & 30.00 & 53 & 44.17 & 31 & 25.83 \\
\hline 6. & $\begin{array}{l}\text { Provides knowledge } \\
\text { about coconut } \\
\text { innovations }\end{array}$ & 34 & 28.33 & 57 & 47.5 & 29 & 24.17 \\
\hline 7. & $\begin{array}{l}\text { Motivates the app users } \\
\text { to adopt the innovations } \\
\text { in their farm }\end{array}$ & 35 & 29.17 & 58 & 48.33 & 27 & 22.5 \\
\hline
\end{tabular}


Table.3 Distribution of the respondents according to their perceived effectiveness of the coconut expert system app

\begin{tabular}{|l|c|c|c|c|c|c|c|}
\hline S. No. & Perception statement & \multicolumn{2}{|c|}{ Highly satisfied } & \multicolumn{2}{|c|}{ Satisfied } & \multicolumn{2}{|c|}{ Not satisfied } \\
\hline $\mathbf{1}$ & $\mathbf{A}$ & $\begin{array}{c}\text { Contents of the app } \\
\text { frequency }\end{array}$ & Per cent & frequency & percent & Frequency & Per cent \\
\hline $\mathbf{1 .}$ & $\begin{array}{c}\text { Understanding of the } \\
\text { message }\end{array}$ & 20 & 16.67 & 67 & 55.83 & 33 & 27.5 \\
\hline $\mathbf{2 .}$ & $\begin{array}{c}\text { Accuracy of the } \\
\text { message }\end{array}$ & 26 & 21.67 & 71 & 59.17 & 23 & 19.16 \\
\hline $\mathbf{3 .}$ & $\begin{array}{c}\text { Presentation of } \\
\text { complex ideas }\end{array}$ & 35 & 29.16 & 56 & 46.67 & 29 & 24.17 \\
\hline $\mathbf{4 .}$ & $\begin{array}{c}\text { Clarity of message } \\
\mathbf{5 .}\end{array}$ & $\mathbf{2 0}$ & 41.67 & 49 & 40.83 & 21 & 17.5 \\
\hline $\mathbf{6 .}$ & $\begin{array}{c}\text { Relevancy of message } \\
\text { Reinforcement of key }\end{array}$ & 33 & 27.5 & 57 & 47.5 & 30 & 25 \\
\hline & $\begin{array}{c}\text { ideas } \\
\text { Multidisciplinary }\end{array}$ & 41 & 34.16 & 53 & 44.17 & 26 & 21.67 \\
\hline
\end{tabular}

More than half of the respondents $(57.50 \%)$ possessed medium level of extent of utilization, followed by 24.17 per cent of the respondents possessed low level of extent of utilization and remaining 18.33 per cent of the respondents possessed high level of extent of utilization respectively.

The perception of coconut growers shed the light on difficulties encountered in using expert system by them.

These results of the study will help the designer of the expert system to modify the content and procedures to suit the expectation of end users.

The extension workers have to conduct demonstrations, awareness creation and training to the users in handling and using various android app will help in improving their skills and effective utilization.

Overall, there is greater need on the part of government to focus on improving information delivery system.

\section{References}

Hiremath, S.U and Tiwari, P. 2011. Use of Advanced Communication Media by Extension Personnel for Rural Development. 6th National Extension Education Congress, Goa.

Rizvi, S. M. H., 2010. Livelihood Solutions through Mobile Technology: An Assessment Technical Paper No. 1. Rural Research Centre, Institute of Rural Research and Development (IRRAD), Gurgaon, Haryana (India).

Sife, A.S. Kiondo and J.G. Lyimo macha. 2010. Contribution of mobile phones to rural livelihoods and poverty reduction in Morongo region, Tanzania, the electronic journal of information system in development countries, 1-40.

Tripathi, k. p., 2011. A review on knowledge based expert system; concept and architecture, IJCA special issue on artificial intelligence techniques- novel approaches \& practical applications (4); 21-25, 2011. 


\section{How to cite this article:}

Aravind, A., R. Raja Sekaran, C. Karthikeyan and Gangai Selvi, R. 2019. Extent of Utilization of Android App on Coconut Expert System and its Effectiveness as Perceived by the Coconut Farmers in Kanyakumari District of Tamil Nadu. Int.J.Curr.Microbiol.App.Sci. 8(11): 24342439. doi: https://doi.org/10.20546/ijcmas.2019.811.281 